\title{
Pajak dan Strategi Bisnis
}

\section{Evaluasi Pungutan Pajak Restoran dan Penetapan Harga Jual}

\section{Oleh:Irsan Nudin Idrus S.E}

Pajak merupakan upaya pemerintah dalam pemerataan pembangunan dan keadilan sosial, hal ini sejalan dengan sila kelima Pancasila yakni dengan mengalihkan dana dari sektor swasta ke pemerintah. Pajak sejatinya telah ada sejak zaman kepemimpinan monarki atau kerajaan, pada saat itu lebih dikenal dengan nama upeti atau di maluku utara dikenal dengan sistem balasteng. Balasteng atau upeti dengan pajak pada prinsipnya sama bahwa merupakan iuran wajib yang bersifat memaksa dan tanpa mendapatkan balasan/prestasi langsung, namun demikian terdapat perbedaan mendasar antara pajak dan balasteng. Balasteng atau upeti pada zaman monarki atau kerajaan bisa berupa hasil pertanian,hewan ternak, atau bahakan emas dari hasil pertambangan dan digunakan untuk menjamin kesejahteraan dan kenyamanan kelompok/golongan tertentu(keluarga kerajaan/penguasa), pajak merupakan transformasi dari sistem balesteng namun dalam penerapan dan penggunaannya lebih memperhatikan sisi keadalilan dan kebermanfaatan, maka pada saat ini pajak dapat dijadikan alat percepatan pembnguanan dan pemertaan dimana hasil penerimaan pajak digunakan untuk mebiayai APBD/APBN, pajak juga dijadikan alat pengendalian untuk peredaran barang tertentu dan proses operasional kegiatan tertentu dengan kebijakan bea dan cukai (alkhol, bahan kimia, rokok.dll).

Pajak di indonesia pada pemungutan dan penggunaannya dibedakan atas dua jenis pajak yakni pajak daerah dan pajak nasional. Dalam ketentuan Undang-undang Negara Republik Indonesia Nomor 28 tahun 2009 Pasal 1 (10) yang dimaksud dengan pajak daerah yang selanjutnya disebut pajak adalah iuran wajib/ kontribusi wajib kepada daerah yang terutang oleh orang pribadi atau badan yang bersifat memaksa berdasarkan Undang-undang, dengan tidak mendapatkan imbalan secara langsung dan digunakan untuk keperluan Daerah bagi sebesar-besarnya kemakmuran rakyat. Selajutnya dalam ayat 22 UU No.28 Tahun 2009 menyebutkan bahwa restoran merupakan salah satu objek pajak yang kemudian dijelaskan dalam bab II Bagian Satu tentang Jenis Pajak.

Bagian kedelapan dari UU Nomor 28 Tahun 2009 menyebutkan bahwa yang dimaksud dengan pajak restoran adalah semua pelayanan yang disediakan oleh restoran meliputi penjualan makanan dan minuman yang dikonsumsi oleh pembeli (Ps.37 (1)(2)) dan yang tidak termasuk dalam objek pajak restoran adalah pelayanan yang disediakan oleh restoran yang nilai penjualannya tidak melebihi batas tertentu yang ditetapkan dengan peraturan daerah (Ps.37 (3)). Besaran tarif pajak restoran yang disyaratkan UU Nomor 28 tahun 2009 pada pasal 40 paling tinggi 10\% dan tarif di daerah ditetapkan kemudian melalui peraturan daerah masing-masing dengan mempertimbangan kondisi daerah tersebut, faktanya menunjukan hampir di setiap daerah pemerintah menetapkan tarif tertinggi yakni $10 \%$, hal ini sangat wajar karena pemerintah pasti akan berupaya untuk memaksimalkan pendapatan daerah. 
Kondisi di atas akan sangat berpengaruh pada penentuan harga jual dari pelayanan yang disediakan oleh wajib pajak (penyedia layanan Ps.39(2)) hali ini disebakan karena dasar penentuan besaran pokok pajak yang harus disetor adalah dengan mengalikan tarif pajak dengan harga jual aslinya atau besaran uang yang harusnya diterima oleh pihak penyedia layanan(Ps.40(2)). Dengan adanya regulasi ini maka secara otomatis harga jual akan mengalami kenaikan sebesar $10 \%$ dari harga aslinya, akumulasi tersebut mungkin tidak terlalu besar bila pembelian yang dilakukan dalam jumlah satuan, namun bagaimana jika jumlah yang dibeli dalam jumlah yang lebih banyak? maka akumulasi selisih bayar dari harga jualnya yang ditambahkan tarif pajak restoran akan sangat terlihat.

Permasalahan tersebut akan menjadi bumerang bagi subjek pajak restoran bila dalam penerapan pajak restoran terdapat kesalahan interprestasi penerapan karena kurangnya informasi baik dari pihak wajib pajak(pembeli Ps.38(2)) maupun subjek pajak. Misalkan subjek pajak dalam penetapan harga jual dalam informasi harganya dipisahkan dari tarif pajak restoran sehingga disaat melakukan pembayaran terdapat selisih sebesar $10 \%$ kondisi ini mungkin tidak masalah jika pembelian yang dilakukan dalam jumlah satuan namun tentu akan terlihat selisihnya bila pembelian yang dilakukan dalam jumlah besar, misalnya harga jual nasi goreng Rp 25.000 belum termasuk pajak restoran jika dibeli sebanyak 20 unit/bungkus maka uang yang harus dibayar @Rp 500.000 jika dikalikan dengan tari pajak restoran maka terdapat tambahan uang yang harus dikeluarkan sebesar Rp50.000,- kondisi tersebut akan samakin terlihat jika dasar pengenaan pajak akumulasinya lebih besar. Maka ketentuan dalam undang-undang ini juga dapat berpengaruh pada tingkat persaingan bisnis restoran dewasa ini yang sangat komptetif dalam menjaga loyal market dan potensi marketnya. Untuk itu diperlukan strategi bisnis dalam penentuan harga jual dan pelayanan yang baik untuk menjaga bisnis agar tetap berada didalam persaingan.

Harga mengandung pengertian, suatu nilai tukar dari produk barang atau pun jasa yang umumnya dinyatakan dalam satuan moneter (Rupiah, Dollar, Yen dll). Dalam dunia bisnis harga mempunyai banyak nama, sebagai contoh dalam dunia perdagangan produk disebut harga, dalam dunia perbankan disebut bunga, atau dalam bisnis jasa akuntansi, konsultan disebut fee, biaya transportasi taxi, telepon disebut tariff sedangkan dalam dunia asuransi disebut premi.

Menurut Kotler (2001:439) Harga adalah sejumlah uang yang dibebankan atas suatu produk atau jasa, atau jumlah dari nilai tukar konsumen atas manfaat-manfaat karena memiliki atau menggunakan produk atau jasa tersebut. Monroe (1990) menyatakan bahwa harga merupakan pengorbanan ekonomis yang dilakukan pelanggan untuk memperoleh produk atau jasa. Selain itu harga adalah salah satu faktor penting bagi konsumen dalam mengambil keputusan untuk melakukan transaksi atau tidak.

Berdasarkan definisi harga diatas maka dapat disimpulkan harga adalah sejumlah uang yang harus dikeluarkan oleh konsumen untuk mendapatkan produk atau jasa yang dibelinya guna memenuhi kebutuhan maupun keinginannya dan umumnya dinyatakan dalam satuan moneter (Rupiah, Dollar, Yen dll). Sedangkan penetapan harga adalah suatu proses untuk menentukan seberapa besar pendapatan yang akan diperoleh atau diterima oleh 
perusahan dari produk atau jasa yang di hasilkan. Penetapan harga telah memiliki fungsi yang sangat luas di dalam program pemasaran. Menetapkan harga berarti bagaimana mempertautkan produk kita dengan aspirasi sasaran pasar, yang berarti pula harus mempelajari kebutuhan, keinginan, dan harapan konsumen.

Dalam penetapan harga, produsen harus memahami secara mendalam besaran sensitifitas konsumen terhadap harga. Menurut Roberto pada buku Applied Marketing Research, bahwa dari hasil penelitian menyebutkan isu utama yang berkaitan dengan sensitifitas harga yaitu; elasitas harga dan ekspektasi harga. Sedangkan pengertian dari elasitas harga adalah:

Konsumen cenderung memberikan respon yang lebih besar atas setiap rencana kenaikan dibandingkan dengan kenyataan pada saat harga tersebut naik. Konsumen akan lebih sensitive terhadap penurunan harga dibandingkan dengan kenaikan harga. Elastisitas konsumen akan berkurang ketika melakukan shopping dengan teman atau dipengaruhi oleh sales person.

Dengan kata lain harga dan penetapan harga adalah suatu proses yang harus dilakukan oleh perusahaan untuk memberikan nilai suatu produk atau jasa dengan mengkalkulasikan terlebih dahulu segala macam biaya yang dikeluarkan untuk memperoleh keuntungan serta mempertimbangkan faktor-faktor yang mempengaruhi permintaan selain harga.

Dalam teori ekonomi klasik, setiap perusahaan selalu berorientasi pada seberapa besar keuntungan yang akan diperoleh dari suatu produk atau jasa yang dimilikinya, sehingga tujuan penetapan harganya hanya berdasarkan pada tingkat keuntungan dan perolehan yang akan diterimanya. Namun di dalam perkembangannya, tujuan penetapan harga bukan hanya berdasarkan tingkat keuntungan dan perolehannya saja melainkan berdasarkan pertimbanganpertimbangan non ekonomis lainnya.

Berikut adalah tujuan penetapan harga yang bersifat ekonomis dan non ekonomis;

1. Memaksimalkan Laba

Penetapan harga ini biasanya memperhitungkan tingkat keuntungan yang ingin diperoleh. Semakin besar marjin keuntungan yang ingin didapat, maka menjadi tinggi pula harga yang ditetapkan untuk konsumen. Dalam menetapkan harga sebaiknya turut memperhitungkan daya beli dan variabel lain yang dipengaruhi harga agar keuntungan yang diraih dapat maksimum.

2. Meraih Pangsa Pasar

Untuk dapat menarik perhatian para konsumen yang menjadi target market atau target pasar maka suatu perusahaan sebaiknya menetapkan harga yang serendah mungkin. Dengan harga turun, maka akan memicu peningkatan permintaan yang juga datang dari market share pesaing atau kompetitor, sehingga ketika pangsa pasar tersebut diperoleh maka harga akan disesuaikan dengan tingkat laba yang diinginkan 
3. Return On Investment (ROI) / Pengembalian Modal Usaha

Setiap usaha menginginkan tingkat pengembalian modal yang tinggi. ROI yang tinggi dapat dicapai dengan jalan menaikkan profit margin serta meningkatkan angka penjualan.

4. Mempertahankan Pangsa Pasar

Ketika perusahaan memiliki pasar tersendiri, maka perlu adanya penetapan harga yang tepat agar dapat tetap mempertahankan pangsa pasar yang ada

5. Tujuan Stabilisasi Harga

Dalam pasar yang konsumennya sangat sensitif terhadap harga, bila suatu perusahaan menurunkan harganya, maka para pesaingnya harus menurunkan pula harga mereka. Kondisi seperti ini yang mendasari terbentuknya tujuan stabilisasi harga dalam industri-industri tertentu (misalnya minyak bumi). Tujuan stabilisasi dilakukan dengan jalan menetapkan harga untuk mempertahankan hubungan yang stabil antara harga suatu perusahaan dan harga pemimpin industri (industry leader)

6. Menjaga Kelangsungan Hidup Perusahaan

Perusahaan yang baik menetapkan harga dengan memperhitungkan segala kemungkinan agar tetap memiliki dana yang cukup untuk tetap menjalankan aktifitas usaha bisnis yang dijalani.

Tujuan-tujuan dalam penetapan harga ini mengindikasikan bahwa pentingnya perusahaan untuk memilih, menetapkan dan membuat perencanaan mengenai nilai produk atau jasa dan tujuan yang ingin dicapai oleh perusahaan atas produk atau jasa tersebut.Setelah perusahaan menentukan dan menetapkan tujuan yang akan dicapai, maka langkah atau tahapan selanjutnya adalah menentukan metode penetapan harga. Secara umum metode penetapan harga terdiri dari 3 macam pendekatan, yakni ;

1. Penetapan harga berdasarkan biaya

a. Penetapan Harga Biaya Plus

Didalam metode ini, harga jual per unit ditentukan dengan menghitung jumlah seluruh biaya per unit ditambah jumlah tertentu untuk menutupi laba yang dikehendaki pada unit tersebut ( margin )

Rumus : Biaya Total + Margin = Harga Jual

b. Penetapan Harga Mark-Up

Untuk metode Mark-up ini, harga jual per unit ditentukan dengan menghitung harga pokok pembelian per unit ditambah ( mark-up ) jumlah tertentu

Rumus : Harga Beli + Mark-Up = Harga Jual

c. Penetapan Harga BEP ( Break Even Point )

Metode pentapan harga berdasarkan keseimbangan antara jumlah total biaya keseluruhan dengan jumlah total penerimaan keseluruhan.

Rumus : BEP $\Rightarrow$ Total Biaya $=$ Total Penerimaan

2. Penetapan Harga berdasarkan Harga Pesaing/Kompetitor 
Penetapan harga dilakukan dengan menggunakan harga kompetitor sebagai referensi, dimana dalam pelaksanaannya lebih cocok untuk produk yang standar dengan kondisi pasar oligopoli. Untuk menarik dan meraih para konsumen dan para pelanggan, perusahaan biasanya menggunakan strategi harga. Penerapan strategi harga jual juga bisa digunakan untuk mensiasati para pesaingnya, misalkan dengan cara menetapkan harga di bawah harga pasar dengan maksud untuk meraih pangsa pasar.

3. Penetapan Harga Berdasarkan Permintaan

Proses penetapan harga yang didasari persepsi konsumen terhadap value/nilai yang diterima (price value), sensitivitas harga dan perceived quality. Untuk mengetahui value dari harga terhadap kualitas, maka analisa Price Sensitivity Meter (PSM) merupakan salah satu bentuk yang dapat digunakan. Pada analisa ini konsumen diminta untuk memberikan pernyataan dimana konsumen merasa harga murah, terlalu murah, terasa mahal dan terlalu mahal dan dikaitkan dengan kualitas yang diterima.

Strategi penetapan harga adalah tahapan dimana perusahaan mengklasifikasikan dan menggolongkan produk atau jasa yang dihasilkannya merupakan 'produk baru' yang belum memiliki konsumen loyal/tetap atau 'produk yang telah beredar' yang telah memiliki pangsa pasar tersendiri. Strategi penetapan harga ini juga berhubungan dengan siklus kehidupan produk (Product Life Cycle) dimana suatu produk memiliki empat tahapan utama yakni, Perkenalan, Pertumbuhan, Kematangan dan Penurunan. Secara khusus strategi penetapan harga ini terdiri dari ;

\section{Produk Baru}

Dalam menetapkan strategi penetapan harga yang efektif untuk produk baru atau tahap perkenalan ini terdapat 2 (dua) alternatif strategi penetapan harga, yaitu

1. Harga Mengapung (Skimming Price)

Memberikan harga tinggi untuk menutup biaya dan menghasilkan laba maksimum (perusahaan dapat meyakinkan konsumen bahwa produknya berbeda dengan produk sejenis yang lain.) Pendekatan skimming sangat efektif jika terdapat diferensiasi harga pada segmen tertentu dan pesaing relatif sedikit. Skimming juga dapat dimanfaatkan untuk membatasi permintaan sampai perusahaan merasa siap untuk melakukan produksi masal. Apalagi skimming dapat meningkatkan nilai produk menjadi sangat prestisius.

2. Harga Penetrasi

Memberikan harga rendah untuk menciptakan pangsa pasar dan permintaan, strategi ini dapat diterapankan pada situasi pasar tidak terfragmentasi ke dalam segmen yang berbeda, serta produk tersebut tidak mempunyai nilai simbolis yang tinggi. Pendekatan ini juga efektif terhadap sasaran pasar yang sensitif harga. 


\section{Produk Yang Telah Beredar}

Strategi penetapan harga untuk produk yang telah beredar ini tentunya tidak terlepas dari posisi produk atau jasa tersebut dari siklus kehidupan produk, dalam hal ini tahapan siklusnya berada pada 3 (tiga) tingkatan berikutnya setelah perkenalan yakni;

1. Tahap Pertumbuhan

Pada tahap pertumbuhan ini ditandai dengan penjualan meningkat disertai munculnya pesaing. Pada awalnya terjadi pertumbuhan yang cepat, strategi yang diterapkan adalah tetap mempertahankan harga produk/pasar. Ketika pertumbuhan melambat, terapkan strategi harga agresif ; menurunkan harga untuk mendorong penjualan sekaligus menghadapi persaingan yang semakin ketat.

2. Tahap Kematangan

Pada tahap kematangan, fleksibilitas harga merupakan kunci efektivitas strategi penetapan harga. Pada tahapan ini perusahaan harus benar-benar responsif terhadap situasi pasar, konsumen maupun pesaing. Strategi penetapan harga dapat menggunakan 'psikologis konsumen' maupun 'pemotongan harga' (diskon), sehingga perusahaan dapat menjaga loyalitas konsumen (pangsa pasar) dan meningkatkan jumlah permintaan dan keuntungan yang diperoleh.

3. Tahap Penurunan

Tahap penurunan produk atau jasa ditandai dengan menurunnya jumlah permintaan secara terus-menerus, sebagai tahap terakhir daur hidup produk terdapat dua alternatif langkah utama yang dapat dipilih. Pertama, strategi diskonting (pemotongan harga) Kedua, mempertahankan harga tetapi memotong biaya-biaya yang berhubungan dengan produk, terutama pengeluaran untuk promosi.

Sumber: https://ekonomiana.wordpress.com/tag/strategi-penetapan-harga/ 